University of Michigan Law School

University of Michigan Law School Scholarship Repository

Articles

Faculty Scholarship

2011

\title{
Money on the Table: Why the U.S. Should Tax Inbound Capital Gains
}

Reuven S. Avi-Yonah

University of Michigan Law School, aviyonah@umich.edu

Available at: https://repository.law.umich.edu/articles/817

Follow this and additional works at: https://repository.law.umich.edu/articles

Part of the Business Organizations Law Commons, Legislation Commons, Taxation-Federal Commons, and the Taxation-Transnational Commons

\section{Recommended Citation}

Avi-Yonah, Reuven S. "Money on the Table: Why the U.S. Should Tax Inbound Capital Gains." Tax Notes Int'l 63, no. 1 (2011): $41-7$.

This Article is brought to you for free and open access by the Faculty Scholarship at University of Michigan Law School Scholarship Repository. It has been accepted for inclusion in Articles by an authorized administrator of University of Michigan Law School Scholarship Repository. For more information, please contact mlaw.repository@umich.edu. 


\title{
Money on the Table: Why the U.S. Should Tax Inbound Capital Gains
}

\author{
by Reuven S. Avi-Yonah
}

Reuven S. Avi-Yonah is the Irwin I. Cohn Professor of Law and Director, International Tax LLM, at the University of Michigan. The author would like to thank Yariv Brauner, Ehab Farah, Oz Halabi, and Roy Rohatgi for their helpful comments.

$\mathbf{O}$ n March 21, 2011, AT\&T announced that it will buy T-Mobile from Deutsche Telekom for $\$ 39$ billion. This transaction will be tax free to Deutsche Telekom (DT) not because it qualifies as a reorganization, but because DT is a foreign corporation and capital gains of nonresidents are generally not subject to U.S. taxation because they are deemed to be foreign source. Also, DT is protected from taxation by article 13(5) of the Germany-U.S. tax treaty, which provides that capital gains are generally taxable only by the country of residence.

However, Germany will not tax DT on its gain, either, because like most OECD countries, it does not tax gains on the sale of shares that qualify for the participation exemption. ${ }^{1}$ Thus, the portion of the $\$ 39$ billion that represents gain will escape taxation altogether.

Is this result justified? From an economic perspective, the answer is no. A capital gain on the sale of shares is the sum of the accumulated earnings of the company plus the present value of its future anticipated earnings. If a U.S. company had distributed those earnings to its foreign parent as a dividend, they would have usually been subject to tax by the U.S. While the U.S. company is subject to tax on its income as it earns it, under our tax system the parent should also be subject to tax on a dividend of the same earn-

\footnotetext{
${ }^{1}$ For a survey of the practice in OECD countries, see Joint Committee on Taxation, "Background and Selected Issues Related to the U.S. International Tax System and Systems that Exempt Foreign Business Income," JCX-33-11 (May 20, 2011).
}

ings. ${ }^{2}$ There is no reason not to treat capital gains in the same way as dividends since they represent the same earnings. ${ }^{3}$ If DT had been a U.S. corporation, it would have been subject to full taxation on the gain inherent in the $\$ 39$ billion, without even the benefit of a lower rate.

Moreover, it is likely that the economic source of the $\$ 39$ billion is mostly from the U.S. T-Mobile is a cellular phone service provider, and most of the value that underlies its earnings comes from the U.S. market, not from innovations supplied by its parent DT. Thus, as between Germany and the U.S., it is likely that the U.S. has the better claim to tax the gain portion of the $\$ 39$ billion. Whatever contribution DT made is probably reflected in its basis in the shares, which is not taxable.

\footnotetext{
${ }^{2}$ As long as we do not adopt full integration, dividends will generally continue to be taxed in the hands of shareholders. I do not believe we are likely to adopt full integration, nor do I think we should, especially in the international context. See Avi-Yonah, "Back to the 1930s? The Shaky Case for Exempting Dividends," Tax Notes Int'l, Jan. 6, 2003, p. 91, Doc 2002-27880, or 2003 WTD 3-16.

${ }^{3}$ There are two reasons why capital gains of foreign sellers should be taxed even if dividends are not (as happens under some of our recent treaties where the direct dividend withholding tax rate is zero, including the Germany-U.S. treaty). First, taxing capital gains is a backstop to inadequate inbound transfer pricing enforcement, which leads to undertaxation of the subsidiary being sold. Second, in mergers and acquisitions frequently the price paid for the target is exaggerated beyond a reasonable present value of future earnings, which is a pure windfall to the selling parent. That was certainly true in BT/MCI, when BT was outbid by Worldcom, which later had to exaggerate its earnings to justify the premium it paid.
} 
Why, then, is it U.S. policy and practice not to tax gains on inbound foreign direct investment (FDI), given that the residence country is very unlikely to tax such gains? After all, under the single tax principle as articulated by U.S. policymakers from T.S. Adams onward, double nontaxation amounts to "leaving money on the table."

The main reason we do not tax capital gains of nonresidents is administrative: In the case of portfolio capital gains, it is very hard to administer the tax. The shares of U.S. corporations are publicly traded on many foreign stock exchanges, and it would be very difficult for the U.S. to enforce a tax on portfolio capital gains when both buyer and seller are nonresidents.

But this rationale does not apply to sales of large blocks of stock. In that case, the buyer wants to obtain the vote, and therefore the stock needs to be registered in its name. Before that happens, the seller needs to show the company that it filed a return and paid the tax. Capital gains tax on the sale of large blocks of stock is enforceable, just like the use tax on cars is enforceable because of the need to register the car. Capital gains tax on portfolio shares is not enforceable, like the use tax on other consumer items.

Accordingly, the same OECD countries that grant an exemption from capital gains tax on sales of large blocks of shares by their residents sometimes tax such sales by nonresidents. That is also the general policy of non-OECD countries like China and India. ${ }^{4}$ While the OECD model treaty provides for residence taxation of all capital gains, the U.N. model permits source taxation of large blocks of shares and so do many actual treaties of both OECD and non-OECD countries.

The U.S. has always followed the OECD model in exempting capital gains from source-based taxation in its model treaties. However, some U.S. treaties with both OECD and non-OECD countries provide for source-based taxation of such gains. ${ }^{5}$

The U.S. also has a model for taxing capital gains at source: It taxes such gains on real estate holdings and on the shares of U.S. corporations whose value derives primarily from U.S. real estate. This has been the case since the Foreign Investment in Real Property Tax Act, which was a treaty override enacted in 1980. The same policy is now included in most U.S. treaties and in the U.S. and OECD models.

In my view, it makes no sense to tax sales of real property at source but to exempt large capital gains.

\footnotetext{
${ }^{4}$ See Avi-Yonah, Sartori, and Marian, Global Perspectives on Income Taxation Law (Oxford University Press, 2011), ch. 9.

${ }^{5}$ The following U.S. treaties permit source taxation of capital gains from the sale of large participations: Australia, Bulgaria, Chile, China, India, Israel, Jamaica, Kazakhstan, Mexico, Norway, Russia, Spain, Sri Lanka, Thailand, Trinidad and Tobago, and Turkey. In all of these cases, under our current rules the other country gets to tax these capital gains but we do not.
}

FIRPTA was enacted because of concerns that wealthy foreign investors (mostly from Japan and the Persian Gulf) were buying prime U.S. properties like Rockefeller Center at depressed prices because of a recession their countries were blamed for and would reap large windfall gains when they sold. Those gains never materialized, and ultimately the foreign investors sold at a loss (in the case of Rockefeller Center, under bankruptcy protection). But even if there was a gain, the underlying properties could not be shipped to Tokyo or Dubai.

That is not true for acquisitions of U.S. corporations. When a foreign multinational buys a U.S. target, it can take away the most valuable element of the target, its intellectual property and human capital, and transfer it overseas. It thus benefits from the U.S. even when the acquisition does not produce a taxable gain. Daimler benefited in that way from the purchase of Chrysler, even though it lost money.

When a foreign multinational acquires a U.S. company and then sells it at a gain, that gain belongs at least in part to the U.S. That was true when BT sold MCI for a large gain and it also applies to the DT sale of T-Mobile. If $\mathrm{BP}$ were to sell Amoco, the gain would likewise largely be U.S. source.

There is no reason for the U.S. not to tax such large capital gains by foreign acquirers. The arguments in favor of such taxation are that:

- the gain stems largely from U.S. source;

- such taxation is consistent with the current international norm; and

- the gain will not be taxed by the residence country and therefore not taxing it at source results in double nontaxation.

The arguments against taxation are weak. It will be said that taxation will hinder inbound FDI, but taxation does not seem to hinder inbound FDI into China or the many other countries that apply such a tax. ${ }^{6}$ It will be said that the tax can be avoided by using holding company structures, but China and India have shown that source countries can look through those structures. ${ }^{7}$ Finally, it will be said that taxation is contrary to our treaty policy, but many of our treaties permit it, and in other cases they can be renegotiated or even (if Congress so wishes, as in FIRPTA) overridden.

\footnotetext{
${ }^{6}$ Multinationals have to be in the U.S. for the same reason they have to be China: It's a huge market that is not moving anywhere.

${ }^{7}$ Another argument is the "lock-in" effect of hindering business transactions, but that does not seem to have an impact on domestic taxable sales of subsidiaries. If the tax is a hindrance, a reorganization can achieve the same goal tax free. (AT\&T could give a bit more stock, since it is currently paying 64 percent of the consideration in cash; a reduction below 60 percent could perhaps qualify the transaction as an "A" reorganization.)
} 
In 1992, U.S. House Ways and Means Committee Chair Dan Rostenkowski introduced legislation that imposed U.S. capital gains tax on foreign sellers of large blocks of shares (10 percent or more) in U.S. corporations. The legislation was not a treaty override, although it added an anti-treaty-shopping provision similar to those adopted for the branch profit tax in 1986. It also had antiabuse provisions that addressed holding company structures.

Today, the U.S. faces a large budget deficit and seeks to impose higher burdens on its own multinationals. While that is also justified, there is no reason to let foreigners off the hook, especially since there is much more inbound FDI now than there was in 1992. Congress should adopt the Rostenkowski legislation (reproduced below) now. (For the full text of Rostenkowski's bill, H.R. 5270, see Doc 92-4700 or 92 TNI 23-17.)

\section{Rostenkowski Legislation 102D CONGRESS, 2D SESSION (27 MAY 92)$$
\text { H.R. } 5270
$$

SEC. 301. DISPOSITION OF STOCK IN DOMESTIC CORPORATIONS BY 10-PERCENT FOREIGN SHAREHOLDERS.

(a) GENERAL RULE. - Subpart D of part II of subchapter $\mathrm{N}$ of chapter 1 (relating to miscellaneous provisions) is amended by adding at the end thereof the following new section:

"SEC. 899. DISPOSITION OF STOCK IN DOMESTIC CORPORATIONS BY 10-PERCENT FOREIGN SHAREHOLDERS.

“(a) GENERAL RULE. -

“(1) TREATMENT AS EFFECTIVELY CONNECTED WITH UNITED STATES TRADE OR BUSINESS. - For purposes of this title, if any nonresident alien individual or foreign corporation is a 10-percent shareholder in any domestic corporation, any gain or loss of such individual or foreign corporation from the disposition of any stock in such domestic corporation shall be taken into account -

"(A) in the case of a nonresident alien individual, under section 871(b)(1), or

"(B) in the case of a foreign corporation, under section 882(a)(1),

"as if the taxpayer were engaged during the taxable year in a trade or business within the United States through a permanent establishment in the United States and as if such gain or loss were effectively connected with such trade or business and attributable to such permanent establishment. Notwithstanding section 865, any such gain or loss shall be treated as from sources in the United States.

"(2) 24-PERCENT MINIMUM TAX ON NONRESIDENT ALIEN INDIVIDUALS. -
"(A) IN GENERAL. - In the case of any nonresident alien individual, the amount determined under section 55(b)(1)(A) shall not be less than 24 percent of the lesser of -

"(i) the individual's alternative minimum taxable income (as defined in section 55(b)(2)) for the taxable year, or

"(ii) the individual's net table stock gain for the taxable year.

“(B) NET TAXABLE STOCK GAIN. — For purposes of subparagraph (A), the term 'net taxable stock gain' means the excess of -

"(i) the aggregate gains for the taxable year from dispositions of stock in domestic corporations with respect to which such individual is a 10percent shareholder, over

"(ii) the aggregate of the losses for the taxable year from dispositions of such stock.

"(C) COORDINATION WITH SECTION 897(a)(2). -

"Section 897(a)(2)(A) shall not apply to any nonresident alien individual for any taxable year for which such individual has a net taxable stock gain, but the amount of such net taxable stock gain shall be increased by the amount of such individual's net United States real property gain (as defined in section 897(a)(2)(B)) for such taxable year.

"(b) 10-PERCENT SHAREHOLDER. -

"(1) IN GENERAL. - For purposes of this section, the term '10-percent shareholder' means any person who at any time during the shorter of -

"(A) the period beginning on January 1, 1993, and ending on the date of the disposition, or

"(B) the 5-year period ending on the date of the disposition,

"owned 10 percent or more (by vote or value) of the stock in the domestic corporation.

"(2) CONSTRUCTIVE OWNERSHIP -

“(A) IN GENERAL. - Section 318(a) (relating to constructive ownership of stock) shall apply for purposes of paragraph (1).

“(B) MODIFICATIONS. - For purposes of subparagraph (A) -

"(i) paragraph $(2)(C)$ of section 318(a) shall be applied by substituting ' 10 percent' for ' 50 percent', and

"(ii) paragraph (3)(C) of section 318(a) shall be applied -

"(I) by substituting ' 10 percent' for '50 percent', and

"(II) in any case where such paragraph would not apply but for subclause (I), by considering a corporation as owning the stock (other than stock 
in such corporation) owned by or for any shareholder of such corporation in that proportion which the value of the stock which such shareholder owns in such corporation bears to the value of all stock in such corporation.

"(3) TREATMENT OF STOCK HELD BY CERTAIN PARTNERSHIPS. -

"(A) IN GENERAL. - For purposes of this section, if -

"(i) a partnership is a 10-percent shareholder in any domestic corporation, and

"(ii) 10 percent or more of the capital or profits interests in such partnership is held (directly or indirectly) by nonresident alien individuals or foreign corporations,

"each partner in such partnership who is not otherwise a 10-percent shareholder in such corporation shall, with respect to the stock in such corporation held by the partnership, be treated as a 10-percent shareholder in such corporation.

“(B) EXCEPTION. -

"(i) IN GENERAL. - Subparagraph (A) shall not apply with respect to stock in a domestic corporation held by any partnership if, at all times during the 5-year period ending on the date of the disposition involved -

"(I) the aggregate bases of the stock and securities in such domestic corporation held by such partnership was less than 25 percent of the partnership's net adjusted asset cost, and

"(II) the partnership did not own 50 percent or more (by vote on value) of the stock in such domestic corporation.

"The Secretary may by regulations disregard any failure to meet the requirements of subclause (1) where the partnership normally met such requirements during such 5-year period.

“(ii) NET ADJUSTED ASSET COST. - For purposes of clause (i), the term 'net adjusted asset cost' means -

"(I) the aggregate bases of all of the assets of the partnership other than cash and cash items, reduced by

"(II) the portion of the liabilities of the partnership, not allocable (on a proportionate basis) to assets excluded under subclause (I).

“(C) EXCEPTION NOT TO APPLY TO 50PERCENT PARTNERS. -

"Subparagraph (B) shall not apply in the case of any partner owning (directly or indirectly) more than 50 percent of the capital or profits interests in the partnership at any time during the 5-year period ending on the date of the disposition.

"(D) SPECIAL RULES. - For purposes of subparagraph $(\mathrm{B})$ and $(\mathrm{C})-$ “(i) TREATMENT OF PREDECESSORS. Any reference to a partnership or corporation shall be treated as including a reference to any predecessor thereof.

"(ii) PARTNERSHIP NOT IN EXISTENCE. If any partnership was not in existence throughout the entire 5-year period ending on the date of the disposition, only the portion of such period during which the partnership (or any predecessor) was in existence shall be taken into account.

"(E) OTHER PASS-THRU ENTITIES; TIERED ENTITIES. - Rules similar to the rules of the preceding provisions of this paragraph shall also apply in the case of any pass-thru entity other than a partnership and in the case of tiered partnerships and other entities.

“(c) COORDINATION WITH NONRECOGNITION PROVISIONS; ETC. - "(1) COORDINATION WITH NONRECOGNITION PROVISIONS. -

“(A) IN GENERAL. - Except as provided in subparagraph (B), any nonrecognition provision shall apply for purposes of this section to a transaction only in the case of -

"(i) an exchange of stock in a domestic corporation for other property the sale of which would be subject to taxation under this chapter, or "(ii) a distribution with respect to which gain or loss would not be recognized under section 336 if the sale of the distributed property by the distributee would be subject to tax under this chapter.

"(B) REGULATIONS. - The Secretary shall prescribe regulations (which are necessary or appropriate to prevent the avoidance of Federal income taxes) providing -

"(i) the extent to which nonrecognition provisions shall, and shall not, apply for purposes of this section, and

"(ii) the extent to which -

"(I) transfers of property in a reorganization, and

"(II) changes in interests in, or distributions

from, a partnership, trust, or estate,

"shall be treated as sales of property at fair market value.

"(C) NONRECOGNITION PROVISION. — For purposes of this paragraph, the term 'nonrecognition provision' means any provision of this title for not recognizing gain or loss.

“(2) CERTAIN OTHER RULES MADE APPLICABLE. - For purposes of this section, rules similar to the rules of subsections (g) and (j) of section 897 shall apply.

“(d) CERTAIN INTEREST TREATED AS STOCK. - For purposes of this section - 
"(1) any option or other right to acquire stock in a domestic corporation,

"(2) the conversion feature of any debt instrument issued by a domestic corporation, and

"(3) to the extent provided in regulations, any other interest in a domestic corporation other than an interest solely as creditor,

"shall be treated as stock in such corporation.

“(e) TREATMENT OF CERTAIN GAIN AS A DIVIDEND. - In the case of any gain which would be subject to tax by reason of this section but for a treaty and which results from any distribution in liquidation or redemption, for purposes of this subtitle, such gain shall be treated as a dividend to the extent of the earning, and profits of the domestic corporation attributable to the stock. Rules similar to the rules of section 1248(c) (determined without regard to paragraph (2)(D) thereof) shall apply for purposes of the preceding sentence.

"(f) REGULATIONS. - The Secretary shall prescribe such regulations as may be appropriate to carry out the purposes of this section, including

"(1) regulations coordinating the provisions of this section with the provisions of section 897, and

"(2) regulations aggregating stock held by a group of persons acting together."

(b) WITHHOLDING OF TAX. - Subchapter A of chapter 3 is amended by adding at the end thereof the following new section:

"SEC. 1447. WITHHOLDING OF TAX ON CERTAIN STOCK DISPOSITIONS.

“(a) GENERAL RULE. - Except as otherwise provided in this section, in the case of any disposition of stock in a domestic corporation by a foreign person who is a 10-percent shareholder in such corporation, the withholding agent shall deduct and withhold a tax equal to 10 percent of the amount realized on the disposition.

"(b) EXCEPTIONS. -

“(1) STOCK WHICH IS NOT REGULARLY TRADED. - In the case of a disposition of stock which is not regularly traded, a withholding agent shall not be required to deduct and withhold any amount under subsection (a) if -

"(A) the transferor furnishes to such withholding agent an affidavit by such transferor stating, under penalty of perjury, that section 899 does not apply to such disposition because -

"(i) the transferor is not a foreign person, or

"(ii) the transferor is not a 10-percent shareholder, and
"(B) such withholding agent does not know (or have reason to know) that such affidavit is not correct.

"(2) STOCK WHICH IS REGULARLY TRADED. -

"(A) IN GENERAL. - Except as provided in subparagraph (B), a withholding agent shall not be required to deduct and withhold any amount under subsection (a) with respect to any disposition of regularly traded stock if such withholding agent does not know (or have reason to know) that section 899 applies to such disposition.

“(B) SPECIAL RULE WHERE SUBSTANTIAL DISPOSITION. - If -

"(i) there is a disposition of regularly traded stock in a corporation, and

"(ii) the amount of stock involved in such disposition constitutes 1 percent or more (by vote or value) of the stock in such corporation,

"subparagraph (A) shall not apply but paragraph (1) shall apply as if the disposition involved stock which was not regularly traded.

"(C) NOTIFICATION BY FOREIGN PERSON. - If section 899 applies to any disposition by a foreign person of regularly traded stock, such foreign person shall notify the withholding agent that section 899 applies to such disposition.

“(3) NONRECOGNITION TRANSACTIONS. - A withholding agent shall not be required to deduct and withhold any amount under subsection (a) in any case where gain or loss is not recognized by reason of section 899(c) (or the regulations prescribed under such section).

“(c) SPECIAL RULE WHERE NO WITHHOLDING. - IF -

"(1) there is no amount deducted and withheld under this section with respect to any disposition to which section 899 applies, and

"(2) the foreign person does not pay the tax imposed by this subtitle to the extent attributable to such disposition on the date prescribed therefor, for purposes of determining the amount of such tax, the foreign person's basis in the stock disposed of shall be treated as zero or such other amount as the Secretary may determine (and, for purposes of section 6501, the underpayment of such tax shall be treated as due to a willful attempt to evade such tax).

“(d) DEFINITIONS AND SPECIAL RULES. For purposes of this section -

"(1) WITHHOLDING AGENT. - The term 'withholding agent' means -

"(A) the last United States person to have the control, receipt, custody, disposal, or payment of the amount realized on the disposition, or 
"(B) if there is no such United States person, the person prescribed in regulations.

"(2) FOREIGN PERSON. - The term 'foreign person' means any person other than a United States person.

"(3) REGULARLY TRADED STOCK. - The term 'regularly traded stock' means any stock of a class which is regularly traded on an established securities market.

“(4) AUTHORITY TO PRESCRIBE REDUCED AMOUNT. - At the request of the person making the disposition or the withholding agent, the Secretary may prescribe a reduced amount to be withheld under this section if the Secretary determines that to substitute such reduced amount will not jeopardize the collection of the tax imposed by section 871(b)(1) or 882(a)(1).

"(5) OTHER TERMS. - Except as provided in this section, terms used in this section shall have the same respective meanings as when used in section 899.

“(6) CERTAIN RULES MADE APPLICABLE. - Rules similar to the rules of section 1445(e) shall apply for purposes of this section.

“(e) REGULATIONS. - The Secretary shall prescribe such regulations as may be appropriate to carry out the purposes of this section, including regulations coordinating the provisions of this section with the provisions of sections 1445 and 1446."

(c) EXCEPTION FROM BRANCH PROFITS

TAX. - Subparagraph (C) of section $884(\mathrm{~d})(2)$ is amended to read as follows:

"(C) gain treated as effectively connected with the conduct of a trade or business within the United States under -

"(i) section 897 in the case of the disposition of a United States real property interest described in section 897(c)(1)(A)(ii), or

"(ii) section 899,".

(d) REPORTS WITH RESPECT TO CERTAIN DISTRIBUTIONS. - Paragraph (2) of section 6038B(a) (relating to notice of certain transfers to foreign person) is amended by striking "section 336" and inserting "section 302, 331, or 336".

(e) CLERICAL AMENDMENTS. -

(1) The table of sections for subpart D of part II of subchapter $\mathrm{N}$ of chapter 1 is amended by adding at the end thereof the following new item:

"Sec. 899. Dispositions of stock in domestic corporations by 10-percent foreign shareholders."

(2) The table of sections for subchapter A of chapter 3 is amended by adding at the end thereof the following new item:
"Sec. 1447. Withholding of tax on certain stock dispositions."

(f) EFFECTIVE DATE. -

(1) IN GENERAL. - Except as otherwise provided in this subsection, the amendments made by this section shall apply to dispositions after December 31, 1992, except that section 1447 of the Internal Revenue Code of 1986 (as added by this section) shall not apply to any disposition before the date 6 months after the date of the enactment of this Act.

(2) COORDINATION WITHIN TREATIES. Sections 899 (other than subsection (e) thereof and 1447 of the Internal Revenue Code of 1986 (as added by this section) shall not apply to any disposition by any person if the application of such sections to such disposition would be contrary to any treaty between the United States and a foreign country which was in effect on the date of the enactment of this Act, and at the time of such disposition and if the person making such disposition is entitled to the benefits of such treaty determined after the application of section 894(c) of the Internal Revenue Code of 1986 (as added by section 302 ).

SEC. 302. LIMITATION ON TREATY BENEFITS.

(a) GENERAL RULE. - Section 894 (relating to income affected by treaty) is amended by adding at the end thereof the following new subsection:

“(c) LIMITATION ON TREATY BENEFITS. -

"(1) TREATY SHOPPING. - No foreign entity shall be entitled to any benefits granted by the United States under any treaty between the United States and a foreign country unless such entity is a qualified resident of such foreign country.

“(2) TAX FAVORED INCOME. - No person shall be entitled to any benefits granted by the United States under any treaty between the United States and a foreign country with respect to any income of such person if such income bears a significantly lower tax under the laws of such foreign country than similar income arising from sources within such foreign country derived by residents of such foreign country.

“(3) QUALIFIED RESIDENT. - For purposes of this subsection -

"(A) IN GENERAL. - Except as otherwise prodded in this paragraphs the term 'qualified resident' means, with respect to any foreign country, any foreign entity which is a resident of such foreign country unless -

"(i) 50 percent or more (by value) of the stock or beneficial interests in such entity are (directly or indirectly) by individuals are not residents of such foreign country and who are not United States citizens or resident aliens, or 
"(ii) 50 percent or more of its income is used (directly or indirectly) to meet liabilities to persons who are not residents of such foreign country or citizens or residents of the United States.

“(B) SPECIAL RULE FOR PUBLICLY TRADED ENTITIES. - A foreign entity which is a resident of a foreign country shall be treated as a qualified resident of such foreign country if -

"(i) interests in such entity are primarily and regularly traded on an established securities market in such country, or

"(ii) such entity is not described in subparagraph (A)(ii) and such entity is wholly owned by another foreign entity which is organized in such foreign country and the interests in which are so traded.

“(C) ENTITIES OWNED BY PUBLICLY TRADED DOMESTIC CORPORATIONS. - A foreign entity which is a resident of a foreign country shall be treated as a qualified resident of such foreign country if -

"(i) such entity is not described in subparagraph (A)(ii) and such entity is wholly owned (directly or indirectly) by a domestic corporation, and "(ii) stock of such domestic corporation is primarily and regularly traded on an established securities market in the United States.

"(D) SECRETARIAL AUTHORITY. — The Secretary may, in his sole discretion, treat a foreign entity as being a qualified resident of a foreign country if such entity establishes to the satisfaction of the Secretary that such entity meets such requirements as the Secretary may establish to ensure that individuals who are not residents of such foreign country do not use the treaty between such foreign country and the United States in a manner consistent with the purposes of this subsection.

"(4) FOREIGN ENTITY. - For purposes of this subsection, the term 'foreign entity' means any corporation, partnership, trust, estate, or other entity which is not a United States person."

(b) CONFORMING AMENDMENT. - Paragraph (4) of section 884(e) is amended to read as follows: "(4) QUALIFIED RESIDENT. - For purposes of this subsection, the term 'qualified resident' has the meaning given to such term by section 894(c)(3)."

(c) EFFECTIVE DATE. - The amendments made by this section shall take effect on January 1, 1993, and shall apply to any treaty whether entered into before, on, or after such date. 